\title{
On his Donkey to the Mountain of 'Arafāt: Dr. Van der Hoog and his Hajj Journey to Mecca
}

\author{
Umar Ryad*
}

Many well-known Europeans converted to Islam in various cities during the interwar period. Their new connection with Islam was rooted in a Zeitgeist that inspired a few rich (and sometimes aristocratic) well-educated Europeans to convert to Islam in their search for spiritual paths beyond their original faith. Those European converts were usually privileged men who became impressed by Muslim societies and cultures. In Britain, France and Germany, many of them even became zealous in their eagerness to spread Islam in Europe. ${ }^{1}$

However, there are many isolated conversion stories that have not been told so far. In many of these cases, it is not known what happened to their families and descendants. ${ }^{2}$ Some European converts left behind fascinating records of their "conversion narratives" including their autobiographical statements and other endeavors which they embarked upon in order to prove their new faith to the wider world. One of the dominant narrative genres that converts used to impart details about their reasons for and paths to conversion was their Hajj accounts. Throughout history many European converts embarked upon Hajj journeys either through their public profession of Islam or in disguise. ${ }^{3}$

* The work is much indepted to the European Research Council (ERC) for the financial support of the ERC Starting Grant project "Neither visitors, nor colonial victims: Muslims in interwar Europe" at the University of Utrecht. Also my special thanks are due to John Slight for his fruitful comments on the chapter.

1 Nathalie Clayer \& Eric Germain, Islam in interwar Europe (London: Hurst, 2008), 8-9.

2 Ali Kose, Conversion to Islam: a study ofnative British converts (Kegan Paul International, 1996), 19 .

3 John T.F. Keane, Six months in Meccah: an account of the Mohammedan pilgrimage to Meccah. Recently accomplished by an Englishman professing Mohammedanism (London: Tinsley Brothers, 1881); Richard Burton, Personal narrative of a pilgrimage to el Medinah and Meccah, 2 volumes (London: G. Bell), 1913; Owen Rutter, Triumphant pilgrimage: an english muslim's journey from Sarawak to Mecca (London [etc.]: Harrap, 1937); Eric Rosenthal, From Drury Lane to Mecca:being an account of the strange life and adventures of Hedley Churchward (also known as Mahmoud Mobarek Churchward), an English convert to Islam (Cape Town: Howard Timmins, 1982 reprint of 1931 edition); H. St. John B. Philby, A pilgrim in Arabia (London: The 
By their very nature, Hajj journeys are cross-border activities. European narratives of Hajj in the colonial era especially highlight a significant historical aspect of connections and transfers across European and Islamic religious and cultural boundaries. During that time, a "European" performing the Hajj did not only represent a western "discovery" of Islam, but also often reflected the interests, perspectives, and habits of a group of people in a new religious and cultural context beyond the particular part of the world to which they belonged.

In light of the previous remark, this chapter traces the conversion and pilgrimage story of Dr. P.H. (or Mohammed Abdul-Ali) Van der Hoog (1888-1957), a Dutch bacteriologist and convert to Islam, whose name is intimately connected to one of the most famous cosmetic brands in the Netherlands in the early twenty-first century. ${ }^{4}$ In fact, the conversion of Dutchmen in the Dutch East Indies happened sporadically, but it occurred very rarely in the Netherlands itself. Compared to other European countries (such as Great Britain, France, Austria, or Germany), conversion to Islam in interwar Holland was unusual. Much scholarly attention and controversy has been given to the "genuineness" of the conversion of the well-known Orientalist Christiaan Snouck Hurgronje, who visited Mecca in the 1880 s and wrote extensively about its culture, society and peoples. ${ }^{5}$ Elsewhere I described the life and activities of another Dutch convert Mohammed Ali Van Beetem (d. 1938), who expended much effort to support the small Muslim Indonesian community in The Hague in 1920 s-1930s. ${ }^{6}$

As a contemporary to Snouck Hurgronje and Van Beetem, Van der Hoog represents another significant aspect of Islam in the Netherlands. As this chapter will demonstrate, his distinction relies on his role as a medical doctor who

Golden Cockerel Press), 1943; Lady Evelyn Cobbold, Pilgrimage to Mecca (London: John Murray, 1934). See also Augustus Ralli, Christians at Mecca (London: William Heinemann, 1909);

A.J.B. Wavell, A Modern Pilgrim in Mecca (Constable \& Company Ltd London, 1913).

4 http://www.drvanderhoog.nl/.

5 C. Snouck Hurgronje, Mekka in the Latter Part of the 19th Century: Daily Life, Customs and Learning: The Moslims of the East-Indian Archipelago, introduced by Jan Just Witkam (Leiden: Brill, 2007).

6 See e.g. H.A. Poeze, In het land van de overheerser I: Indonesiërs in Nederland 1600-1950 [In the land of the ruler I: Indonesians in the Netherlands 1600-1950] (Dordrecht: Foris, 1986); Idem, "Early Indonesian emancipation: Abdul Rivai, van Heutsz, and the Bintang Hindia," Bijdragen tot de Taal-, Land- en Volkenkunde 145/1 (1989): 87-106; Akira Nagazumi, "Prelude to the formation of the Perhimpunan Indonesia: Indonesian student activity in the Netherlands in 1916-1917," Proceedings of the seventh IAHA conference, held in Bangkok, 22-26 August 1977 (Bangkok: Chulalongkorn University Press, 1979), 192-219. 
worked in Jeddah, converted to Islam, and later visited Mecca to perform the Hajj. Van der Hoog's account of the Hajj is a lively and at many points humorous literary narrative. In his conversion and experience of the Hajj, he did not identify himself as irrevocably divorced from his western background. His Hajj account is mostly structured around the motifs of his settling in Jeddah and his working life in the port as a medical expert. Throughout his book, he tended to shift between topics including his life story, his stay in Jeddah, remembering his small children in The Netherlands as well as his thoughts on Islam, politics and pan-Islam. This chapter will attempt to analyze the multiple layers and elements of "Europeanness" and "Islamness" that he had tried to stress in his new life in and outside his native county. In other words, we focus on his "layered identities" and elements of his European and Islamic experiences.

Van der Hoog's case is both significant and unique precisely because he is situated at the margins of European cultural and religious history. Examining his activities and writings on Islam and the Hajj reveal him as a liminal figure who tried to define his new religious belonging as a trans-cultural mixture and hybridity that went beyond his original religious and cultural boundaries. Placing him in a wider historical context, he is a distinct example of how someone could transcend the often raised dichotomy between Europe and Islam in the colonial era. In the interwar period, people such as Van der Hoog were pioneer examples of the indigenization of Muslim practices, thoughts, and discourses on European soil.

This chapter is particularly interested in the ways in which he integrated or reclaimed aspects of his Dutch values and norms with an Islamic identity during his Hajj experience and in mainstream Arabian society. What motivated him to convert to Islam? How did he create a new religious world for himself in his homeland? Did his conversion and Hajj experience Islamize his European identity; or had he tried to Europeanize some of his views of Islam and the Hajj? Can we consider Van der Hoog as a European cultural mediator or broker who straddled the numerous divides typical of that crucial period, such as EastWest, colonizer-colonized, or Muslim-non-Muslim?

\section{Early Life and Activities}

Little is known about Van der Hoog's early years. He was born in 1888 as the second child of a general in the Dutch army. As a distinguished secondary school pupil, he wanted to become a painter. ${ }^{7}$ But his father insisted that

7 A telephone call with his daughter F. Gudde-van der Hoog, 16 April 2013. 
his son should, like him, join the army. In order to combine his father's wish with a profession that he also liked, Van der Hoog decided to be a doctor in the Dutch colonial military. ${ }^{8}$ According to the contemporary Dutch press, he finished his Propaedeutisch examen (preliminary exam) of medical studies in Leiden in $1907 .{ }^{9}$ During his study in Leiden, he became the editor-in-chief of the Leiden student's weekly journal, Algemeen Nederl. Studenten-WeekbladMinerva. ${ }^{10}$ In 1911, he finished his graduate exam and in the following year obtained a certificate for the first part of his medical degree. ${ }^{11}$ In 1913, Van der Hoog was promoted to the position of a medical doctor; and in the same year by a royal decree he was appointed as an Officer of Health in the army. ${ }^{12}$

In early August 1913, after his graduation, Van der Hoog left Amsterdam on the steamship Rembrandt for the Dutch East Indies to join the team of Pest Control in the Civil Medical Service in Batavia. ${ }^{13}$ In the colony he married his first wife Annie P.L. Brandon Bravo in Weltevreden (a sub-district of Central Jakarta in the colonial time, currently Sawah Besar). ${ }^{14}$

According to the Dutch consul at Jeddah, Daniel van der Meulen (18941989), Van der Hoog became a prolific writer in the Dutch press with a "malicious" pen during his work in the army. ${ }^{15}$ Writing anonymously, he even made a harsh critique of the army. When his name was identified as the author, he was transferred to a jungle post in central Borneo as punishment. ${ }^{16}$ In fact, this article was published in 1915 in the Bataviaasch Nieuwsblad under Van der Hoog's

8 D. van der Meulen, Faces in Shem (London: John Murray, 1961), 16.

$9 \quad$ Het Nieuws van den Dag: Kleine Courant, 15 July 1907.

$10 \quad$ Het Nieuws van den Dag: Kleine Courant, 3 December 1908.

11 Nieuwe Tilburgsche Courant, 20 June 1911; De Tijd: Godsdienstig-staatkundig Dagblad, 20 June 1911; Nieuwe Rotterdamsche Courant; Algemeen Handelsblad, 1 March 1912.

12 Nieuwe Rotterdamsche Courant; Algemeen Handelsblad, 10 January 1913; Het nieuws van den Dag: Kleine Courant, 5 February 1913; Bataviaasch Nieuwsblad, 10 March 1913; Het Nieuws van den Dag voor Nederlandsch-Indië, 17 March 1913; Het Nieuws van den Dag: Kleine Courant, 16 April 1913; Algemeen Handelsblad, 1 August 1913; Het nieuws van den Dag voor Nederlandsch-Indië, 26 August 1913.

13 Bataviaasch Nieuwsblad, 29 July 1913; Het Nieuws van den Dag: Kleine Courant, 23 April 1914; De Tijd: Godsdienstig-staatkundig Dagblad; Algemeen Handelsblad, 5 February 1913; Het Nieuws van den Dag voor Nederlandsch-Indië, 11 September 1913; Het Nieuws van den Dag voor Nederlandsch-Indië, 27 March 1914; Algemeen Handelsblad, 22 April 1914.

14 Bataviaasch Nieuwsblad, 19 March 1914; Bataviaasch Nieuwsblad, 25 March 1914.

15 Van der Meulen, Faces in Shem, 16-17; see for example, Bataviaasch Nieuwsblad, 18 January 1915 .

16 Van der Meulen, Faces in Shem, 16. 
name. ${ }^{17}$ It was mainly a critical piece to the Union of Officers, in which Van der Hoog explained how he did not appreciate the hierarchal military ranking in the colony. A debate erupted in the local press of Java about the value of this union to lower military ranks. Considering himself a "half military" man, Van der Hoog believed that the establishment of such committees should not be a matter of formality which ultimately only represented the interests of superior officers. He stated metaphorically that when a "storm" had suddenly exploded in the "pond" of officers, he suddenly saw a few "goldfish" (referring to superior officers) that started angrily to "snap at a large number of sticklebacks" (referring to the lower ranks). He lamented that the goldfish forgot that they had been ordinary sticklebacks in the past. Sticklebacks, Van der Hoog maintained, should understand that their stand was as good, valuable, and powerful as the position of the goldfish, or even better. The goldfish would soon die, whereas sticklebacks still had the whole fullness of life ahead of themselves. ${ }^{18}$

Because of this article, Van der Hoog was transferred to the most remote military jungle post in Borneo in March $1915 .{ }^{19}$ It is reported that in that military camp, Van der Hoog ridiculed the strict military disciplines which had caused a clash between him and the captain of this camp. Van der Hoog declared the captain insane, maneuvered him into a room, and locked him in. Fearing for his life, Van der Hoog fled to the district capital where he was arrested. A year later he was transferred to Banjarmasin, the capital of South Kalimantan. There he was allowed to work at its hospital among the Dayak people, ${ }^{20}$ who were known for their tradition of headhunting practices and propensity for nakedness. With the support of his father's military friends he was allowed to leave the military service with light punishment. ${ }^{21}$

In 1921, Van der Hoog returned to The Netherlands. ${ }^{22}$ The next year he defended his $\mathrm{PhD}$ thesis in medical studies at the University of Leiden on the topic of sexually-transmitted diseases. ${ }^{23}$ In Leiden he started to build a family life and a career as a medical practitioner. But given that he was "a born adventurer," as Van der Meulen put it, Van der Hoog often left his first "wife

17 "Ingezonden: De Officiersvereeniging," Bataviaasch Nieuwsblad, 18 January 1915.

18 "Ingezonden: De Officiersvereeniging," Bataviaasch Nieuwsblad, 18 January 1915.

19 "Een slachtoffer," Het Nieuws van den Dag voor Nederlandsch-Indië, 19 March 1915.

$20 \quad$ Bataviaasch Nieuwsblad, 8 July 1916.

21 Van der Meulen, Faces in Shem, 16-17.

22 Bataviaasch Nieuwsblad, 15 June 1921.

23 Nieuwe Rotterdamsche Courant, 16 March 1922. See P. ven der Hoog, De Bestrijding der Geslachtsziekten (Leiden University, 1922). Cf. Algemeen Handelsblad, 28 February 1923. 
and son, his lucrative practice and his cultured Leiden friends," ${ }^{24}$ travelling as a ship's doctor. In February 1926, Van der Hoog was nominated as the chief medical officer of the Public Health Service in the Dutch Caribbean island of Curacao. ${ }^{25}$ According to Van der Meulen, he clashed with the governor over the latter's dictatorial behavior. ${ }^{26}$ In that year, Van der Hoog took part in the Dutch Colonial Council on Curacao's plans to solve of the problem of drought and water hygiene. He urged the council to regulate the water supply in accordance with hygiene rules and protection against pollution and disinfection. Water coming from different sources should be investigated at laboratories in order to resist bacterial growth. ${ }^{27}$ In a short space of time, Van der Hoog became a founding member of a committee encouraging the improvement of water supply on the island, ${ }^{28}$ but it remains unclear whether the committee met with any success. In October 1926 he resigned his post on Curacao and decided to return to Holland. ${ }^{29}$ In The Netherlands he continued to attack the governor of Curacao over the island's water policy. As his critique had attracted so much attention, the Colonial Office decided he was a liability and therefore unemployable. ${ }^{30}$

\section{A Dutch Adventurer in Arabia}

Two years later, Van der Hoog received an invitation to come to Arabia in order to support the government's medical staff in Jeddah, comprised of Egyptian and Syrian doctors. ${ }^{31}$ This invitation was actually a result of the proceedings of the Congress of the Islamic World held in Mecca in 1926 under the auspices of King Abdul-Aziz Al-Sa'ūd. One of the Congress's aims was "to examine and promote the improvement of security in the holy precincts of the Hijāz; to

\footnotetext{
24 Van der Meulen, Faces in Shem, 16-17.

25 Amigoe di Curacao: Weekblad voor de Curacaosche Eilanden, 13 February 1926; 3 April 1926; 17 July 1926.

26 Van der Meulen, Faces in Shem, 18.

27 "Dr. P.H. van der Hoog over de Watervoorziening," Amigoe di Curacao: Weekblad, 14 August 1926; "Watervoorziening," Amigoe di Curacao: Weekblad voor de Curacaosche Eilanden, 21 August 1926.

28 "Dr. P.H. van der Hoog over de Watervoorziening," Amigoe di Curacao: Weekblad, 14 August 1926; Amigoe di Curacao: Weekblad voor de Curacaosche Eilanden, 28 Agust 1926.

29 "Vaarwel," Amigoe di Curacao: Weekblad voor de Curacaosche Eilanden, 2 October 1926.

$30 \quad$ Van der Meulen, Faces in Shem, 18.

31 Van der Meulen, Faces in Shem, 18.
} 
better the facilities for transportation, health, communications; to facilitate the pilgrimage, and to remove all obstacles which impede the fulfillment of this religious duty; to guarantee the integrity of the Hijāz, and to safeguard its rights." 32

The Dutch consul to Jeddah, Daniel van der Meulen, reported that due to the poor hygienic state among pilgrims, the King had asked him to procure a Dutch doctor to organize the medical service in the city. "A Leyden doctor," he wrote, "was found who was willing to come to Jeddah and see what he could do. A young Syrian doctor was glad to be his assistant and so it began." 33 The nomination of this Dutch bacteriologist also came as a result of the European negotiations regarding the arrangements for the sanitary regulation of the Pilgrimage. Since the First International Sanitary Convention in 1866, Hajj was an important issue for colonial states. During the Thirteenth International Sanitary Convention (1926) in Paris, for example, European health officials viewed the Hajj "as a significant cholera risk, because of the large movement of people to a crowded space with limited sanitary facilities en route." ${ }^{34}$

Van der Hoog arrived in Jeddah at the end of September 1928 to begin his medical duties and stayed for six months. The Dutch press in the Netherlands and in the East Indies welcomed the idea that a Dutchman was selected for the job, and it followed his successful activities with interest. ${ }^{35}$ The Foreign Office dispatched him to Arabia without having consulted the Colonial Department. Consequently, Van der Meulen received a letter from his office headquarters in The Hague to warn him about the newly employed Van der Hoog, because he was known as a trouble-maker in the colonies. ${ }^{36}$ But after a frank conversation with Van der Hoog, Van der Meulen discovered that he was exactly the type of man required. The official and non-official Arab community seemed

32 See, Martin Kramer, Islam Assembled: The Advent of the Muslim Congresses (New York: Columbia University Press, 1986), 186.

33 D. van der Meulen, Don't you hear the thunder: A Dutchman's life story (Brill, 1981), 85.

34 See, Anne Sealey, "Globalizing the 1926 International Sanitary Convention," Journal of Global History 6:3 (November 2011): 453-455; Hugh S. Cumming, "The International Sanitary Conference," American Journal of Public Health 16:10 (1926): 975; Norman HowardJones, The scientific background of the International Sanitary Conferences (Genevan: World Health Orgainzation, 1975).

35 See, “Dr. F.H. Van der Hoog naar Djedda," Het Vaderland: Staat- en Letterkundig Nieuwsblad, 14 September 1928; "Nederlansch-Indie: De Bedevaart naar Mekka," Bataviaasch Nieuwsblad, 17 Septemeber 1928; "Nederlander in de Hedjas," Het Vaderland: Staat- en Letterkundig Nieuwsblad, 25 January 1928.

$36 \quad$ Van der Meulen, Faces in Shem, 18. 
to trust him; and due to his knowledge and experience "his fame as a doctor rose high."37

Van der Hoog's laboratory was placed in the city hospital, where soldiers, policemen, and lower-ranking civil servants were usually treated. In his laboratory, he started his research and vaccine preparation. Van der Hoog gave a detailed description of the unsatisfactory hygiene conditions prevailing in Jeddah during his stay. His first experience with the place was miserable. Urine and faeces were running on the street, which attracted "black clouds" of flies. He found that as soon as patients saw a European face, they would immediately run to him and make beseeching gestures for food. He was surprised to find that the only surgical equipment was a bowl and some rusty medical instruments. In the bowl was some water in which a cigarette butt and a match were floating. Every operation in that hospital was, in his view, equivalent to "murder." Flies swarmed everywhere. On one occasion, Van der Hoog was shocked to see his Syrian assistant doctor sitting down to smoke a cigarette while "a filthy negro" was busy vaccinating a child against smallpox. In the courtyard there were a dozen young cats walking around eating the leftovers in the refuse and faeces. ${ }^{38}$

Van der Hoog's stay in Jeddah coincided with the Hajj season of 1928. He noted that the hygienic condition of Jeddah during the Hajj generally became worse. At the market, meat, vegetables, fruits, treats and fried grasshoppers were covered by thick layers of "billions" of flies. Some distance away, a few sick pilgrims sat in a corner to defecate faeces filled with blood and mucus. ${ }^{39}$ The pilgrims from the Dutch East Indies were viewed as rather unhygienic, although in a better state than pilgrims from other territories. Thousands of poor pilgrims were camping on the street or even outside the city walls amid their own faeces, given the lack of public latrines. ${ }^{40}$ In Jeddah, there was a service for collecting garbage which was run by young men from Africa (takayrna pilgrims). On a donkey cart these men drove through the city collecting all the garbage together by hand, and then directly threw the refuse close to the outside city wall. ${ }^{41}$

Turning to the water supply, Van Der Hoog observed that there were three ways for pilgrims and the town's inhabitants to access water. First of all, there were three condensers which produced sterile water, which became undrinkable during its transportations to houses on donkey carts in old, open kerosene

37 Van der Meulen, Faces in Shem, 19.

38 P.H. van der Hoog, Pelgrims naar Mekka (The Hague: H.P. Leopold's Uitg.-Mij, NV, 1935), 58.

39 Van der Hoog, Pelgrims naar Mekka, 58.

$40 \quad$ Van der Hoog, Pelgrims naar Mekka, 59.

41 Van der Hoog, Pelgrims naar Mekka, 59. 
cans. Secondly, there were water wells outside the city where water was usually carried to the city in leather bags on camels. Thirdly, in the basement of each house there were a few cisterns that would gather rain water during a couple of days every year when it rained. This water became polluted through the presence of mosquitos. Some of the cisterns were also located nearby the military barracks where about 400 soldiers were incapacitated with malaria. ${ }^{42}$

In Jeddah, Van der Hoog was also informed about a similar hygienic situation in Mecca, which was lamentable for a city that saw about two hundred thousand people visit every year. The water of Zamzam usually became infected when people drew it from its source using buckets and cans. Van der Hoog asked some of his friends to bring him some specimens of water and his research showed that it contained 1880 microbes, while the water coming from pipes of Zubayda contained 4638 microbes per cc. ${ }^{43}$ The central source of pollution and stench in Mecca, he was also told, was the public place for animal slaughter, where the "rotten" leftovers of meat after the Sacrifice were thrown after the Hajj every year. He was told that the center of filth in Mecca was the slaughtering place, where animal viscera were deposited. "A European," he asserted, "would only be able to endure it here for a few minutes before becoming nauseous." ${ }^{4}$ It was a challenging task for a hygienist like him to be there. What was surprising for him was the fact that these miserable conditions had arisen not out of necessity, but out of free will. However, he viewed it as an indestructible desire that drove those millions of people to fulfill their religious duties with no fear, which led to their self-destruction through being exposed to these unhygienic conditions. ${ }^{45}$

\section{Conversion to Islam}

In Jeddah, Van der Hoog declared his conversion to Islam in public before his final return to the Netherlands after the Hajj season in 1928, which caused a controversy among the city's European community. Van der Meulen, himself a devoted Protestant Christian, suspected Van der Hoog's real faith as a new Muslim. He asserted that Van der Hoog was only interested in the study of the famous well of Zamzam; and conversion would allow him access to the city. In addition, his Muslim assistants had neither the knowledge nor the means to

\footnotetext{
42 Van der Hoog, Pelgrims naar Mekka, 59.

43 Van der Hoog, Pelgrims naar Mekka, 60.

44 Van der Hoog, Pelgrims naar Mekka, 60.

45 Van der Hoog, Pelgrims naar Mekka, 61.
} 
bring him a sample of the water in the same state as the pilgrims drank it. ${ }^{46}$ It might be relevant to add that Van der Meulen was also strongly convinced that the famous Dutch Orientalist Snouck Hurgronje, famous for his visit to Mecca in the late nineteenth century, died while he was a Christian in his heart, despite his supposed faith in Islam. ${ }^{47}$

Van der Meulen also found that Van der Hoog made his decision of conversion in some haste. He moreover suspected that Van der Hoog was actually more interested in getting material for a number of sensational articles in the Dutch press. His conversion to Islam caused a storm of debate among the European community in Jeddah. In Van der Meulen's words:

A stone dropped into the quiet pool of our western Christian community; one of our sheep had left the fold and had crossed over to the other side. Van der Hoog had become a 'Muslim.' The condemnation of this act was general; and I myself did not expect such a reaction, still less did Van der Hoog, for he naively believed that he would become a sort of a hero: a man who dared. The contrary happened. The so-called Christian community closed its ranks and those who behaved least like Christians were the sharpest in their criticism. ${ }^{48}$

The Dutch newspaper in the Dutch East Indies, Soerabaijasch Handelsblad, reflected a similar impression regarding Van der Hoog's conversion, who had become a "Mohammedan" in order to enter Mecca. This anonymous journalist reported that the Arabs did not have any solid ground to believe that his faith was sincere since he only had to profess that "lä illāha illä Allāh (There is no God, but Allah)." The journalist cynically suspected that Van der Hoog had converted to Islam only in order to "get access to Mecca, rather than to enter the Mohammedan heaven."49 This suspicion, in the journalist's view, seemed warranted, probably because Van der Hoog would be able to gather more materials for his medical studies on "Arab hygiene." The journalist was told that

\footnotetext{
46 Van der Meulen, Faces in Shem, 19.

47 D. van der Meulen, Don't you hear thunder?: A Dutchman's Life Story (Leiden: Brill: 1981), 74-75.

48 Van der Meulen, Faces in Shem, 19-20. See also, as quoted in, Joos Vermeulen, Sultans, slaven en renegaten: de verborgen geschiedenis van de Ottomaanse rijk (ACCO, 2001), 16.

49 "Ter Bedevaart," Soerabaijasch Handelsblad, 10 January 1930; See also, "Christen-Islamieten: Toestanden in en om Mekka," Het Nieuws van den Dag voor Nederlandsch-Indië, 14 January 1930; "Indische Kroniek: Oude bekenden in de buurt van Mekka," Algemeen Handelsblad, 15 January 1930.
} 
Van der Hoog did not observe the fasting of Ramadan. When Van der Hoog left Jeddah on his way to Palestine and Syria, "the faithful in Jeddah noted that, not without Schadefreude, that this new Mohammaden sat to drink an ice cold beer on the board of the steamer on one of the first days of Ramadan." ${ }^{.50}$ After his conversion, Van der Hoog was not immediately allowed into Mecca. Writing in 1930, the unnamed journalist suspected that Van der Hoog recanted his faith when he was refused entry to Mecca. ${ }^{51}$

Shortly after his conversion, Van der Hoog fell ill, and his weak resistance to malaria affected his heart. A high fever struck him and his heart became severely strained. At this moment, Van der Hoog clarified to Van der Meulen in person that "he had never been a sincere Christian; if he could become a sincere Muslim it would be a change for the better." ${ }^{22}$ Nonetheless, Van der Meulen did not believe that this had been the case. After his recovery, Van der Meulen made a sarcastic contrast by denoting that Van der Hoog "found mercy from the God of Christians and Abdul Ali [...] was spared further trial by the Allah of the Muslims." 53

In Jeddah, some Europeans even perceived Van der Hoog's conversion as "betrayal,"54 and others even ostracised him. Even Harry St. John Philby (18851960), the private businessman in Jeddah, became furious about the "tactless haste" with which Van Der Hoog offended Christians and Muslims alike. In that way, Philby argued, "Van der Hoog had queered the pitch for a long time for every candidate for conversion." ${ }^{55}$ In this period, Leopold Weiss (Mohammed Asad, 1900-1990), Jewish-born convert to Islam, was hosted by the Saudi king in Riyad which made him closer to the Palace in many decisions. This made both Philby and Van der Meulen anxious. To Snouck Hurgronje, Van der Meulen wrote: "If Van der Hoog had not made it difficult [by leaving his job and his early departure to The Netherlands] he would, after his conversion to the Mohammadan religion, come in the vicinity of the king and by this would exercise his influence for the sake of the country." ${ }^{\prime 5}$

50 "Ter Bedevaart," Soerabaijasch Handelsblad, 10 January 1930; See also, "Christen-Islamieten: Toestanden in en om Mekka," Het Nieuws van den Dag voor Nederlandsch-Indië, 14 January 1930; "Indische Kroniek: Oude bekenden in de buurt van Mekka," Algemeen Handelsblad, 15 January 1930.

51 Ibid.

52 Van der Meulen, Faces in Shem, 21.

53 Van der Meulen, Faces in Shem, 21.

54 Quoted in Vermeulen, Sultans, 16.

55 Van der Meulen, Faces in Shem, 20.

56 Letter, Daniel van der Meuelen to Snouch Hurgronje, Djeddah, 8 March 1928, Leiden University Library, Or. 8952 A, 1928 (03-08)-1929 (04-03). 
It is ironic that Philby himself converted to Islam in 1931, naming himself 'Abdullāh. It is also worth noting that Van der Hoog was one of Philby's close friends and his medical doctor in Jeddah. Van der Hoog was amazed with Philby's solid faith in the future and revival of Arabia under the rule of King Ibn Sa'ūd. Van der Hoog did not underestimate Philby's role in Arabia, but was in the beginning doubtful about Philby's activities in the country. But he later realized that Philby was not only a representative of the Ford Motor Company, but was able to raise himself as an "apostle of a great Arabia" under Ibn Sa'ūd's rule. ${ }^{57}$

During his early stay in Jeddah, Van der Hoog was invited along with other Arab notables and European residents in Jeddah to Philby's house where they celebrated the second anniversary of the ascension of King Ibn Sa'ùd to the throne of the Hijāz. Van der Hoog decided to attend because for him it was "a good opportunity to see different birds of all sorts in one place. ${ }^{.58}$ There he met the Iraqi medical doctor 'Abdullāh Sa'îd al-Damlūjì (1890-1971), then a deputy of Foreign Affairs of Arabia, who was also celebrating his birthday on that day as well. It was remarkable for Van der Hoog to see the high officials of the Customs Service of Jeddah among the invited group of people. He stated that most of these officials resembled "highwaymen," since civil servants had been recently ordered to let their beards grow. It was of great significance, Van der Hoog sarcastically wrote, that Philby as representative of a commercial company in Jeddah had to keep his relationship with these officials on good terms. ${ }^{59}$ But Van der Hoog's later discussions with Philby had finally convinced him of the "great work" yet to be done in Arabia. ${ }^{60}$

On another level, Van der Hoog's conversion to Islam and his Hajj experience should be viewed within his personal understanding of faith and religion in general. He made it clear that his experience of pilgrimage was a spiritual one. As it might not be entirely convincing or appealing to the secular mindset of his European readership, he tried to pose many rhetorical and philosophical questions regarding the meaning and use of faith and religion to humanity. As a prelude to his Hajj account, he dwelt upon these issues in order to convince or at least to justify to his Dutch readers why he had taken this new step in his life. For him, faith was one of the remarkable human instincts which stimulate man's feelings and thoughts towards a transcendental world. Man therefore places God's worship at the center of that world. However, for many people

\footnotetext{
57 Van der Hoog, Pelgrims, 65.

$5^{8}$ Van der Hoog, Pelgrims, 66.

59 Van der Hoog, Pelgrims, 67.

6o Van der Hoog, Pelgrims, 68-69.
} 
who do not suffer as a result of world events, their faith instinct is usually extremely underdeveloped. But ultimately, it is a matter of upbringing. Parents and teachers who find faith necessary shall always deliberately try to develop this instinct in children. Van der Hoog's experience of faith was more spiritual. As the question of faith is not a common sense issue, it was therefore very difficult for him to reason about it with those who did not primarily believe in the Divine might. In his view, "unbelief" or "the inability to believe" is a decisive spiritual defect in a human being. "A person without faith," he wrote, "does not know what he is talking about. He stands as an illiterate before somebody who could read and write; and wants to talk with him about literature."61

Van der Hoog made a distinction between the Dutch term "godsdienst (literarily, service of God)" and "religie (or religion)." He had a pluralistic vision of religion. To him, the term "religion" refers to the personal psychological relationship of humans with the Infinite Eternal Divine, whereas the other term refers more to the external shaping services that manifest this relationship. But in Van der Hoog's view, Prophet Muhammad's message was the last one. However, he maintained that "although there were numerous small leaders and prophets who had risen after him throughout the centuries, eternal truths were not proclaimed by them." ${ }^{\prime 2}$

In his account, Van der Hoog summed up the internal and external fundamentals of the Islamic faith in a traditional way. Nevertheless, he sometimes explained some of these aspects outside the realm of the Islamic normative tradition. As a medical doctor, for example, he found that Islam stipulates male circumcision in a long line of hygienic tradition known among many ancient peoples, including the Israelites and ancient Egyptians. In order to fulfill its hygienic value, man had probably attached a religious or political meaning to it. ${ }^{63}$ On another level, he accepted the view that after receiving the Divine message, the Prophet Muhammad did not radically break with the old pagan norms of Mecca, such as the ritual of 'Umrah (Minor Pilgrimage), which was kept among the pre-Islamic rites in honor of its established nature. ${ }^{64}$

Due to his illness and family circumstances, Van der Hoog was obliged to cut short his stay in Jeddah and returned to his family. In Leiden he resumed his medical career as a practitioner in a private clinic. His fame in the Dutch press and on the radio at this time was much connected to his popular scientific and medical dermatological contributions on such issues as "taking

\footnotetext{
61 Van der Hoog, Pelgrims, 7-9.

62 Van der Hoog, Pelgrims, 11.

63 Van der Hoog, Pelgrims, 11-14.

64 Van der Hoog, Pelgrims, 21.
} 
care of nails and hands,"65 "ugly legs,"66 "the excessive hair,"67 "face massage,"68 "staying slim,"69 "vegetarian diet,"70 among other conditions. He also started to give public lectures in Leiden about his impressions regarding the "miserable" hygienic state in Arabia, introducing himself to the public under his Arabic name Mohammed Abdul Ali. ${ }^{71}$

Moreover, Van der Hoog tried to clarify some points regarding the western understanding of Oriental and Islamic traditions. In 1931, for example, he responded to a press article under the title, "Vrouwen in het Oosten (Women in the East)," in which a female writer asserted that "as soon as the Sun of Righteousness will begin to shine and the Gospel will triumph over Islam, Muslim women will be freed from her bondage."72 In his response, Van der Hoog asserted that he had no faith in the triumph of the Gospel over Islam anymore. "We Christians," he wrote, "are suffering in this respect under too much overconfidence. It seems therefore very useful to mention in this magazine that the peoples of Asia and Africa have since a while ago begun to divest themselves from the domination of Europe by resistance. The colored races do not wish to acknowledge the 'absolute' superiority of the white man anymore." ${ }^{73}$ The liberation of the Muslim woman from her bondage, he asserted, would occur solely according to the laws of evolution; any triumph over Islam would be achieved without any need of the Gospel. ${ }^{74}$

\section{A Self-Promise: Back Again to Mecca}

However, in the Netherlands Van der Hoog was still determined to return to Mecca for the Hajj. At the point of his departure from Jeddah, he had an inner feeling that he would one day return to Arabia. But a "voice was whispering [in

\footnotetext{
65 "Verzorging van handen en nagels," Het Vaderland: Staat- en letterkundig Nieuwsblad, 14 July 1929 .

66 "Leelijke Beenen," Het Vaderland: Staat- en Letterkundig Nieuwsblad, 7 July 1929.

67 "Het overtollige haar," Het Vaderland: Staat- en Letterkundig Nieuwsblad, 11 August 1929.

68 "Gezichtsmassage," Het Vaderland: Staat- en Letterkundig Nieuwsblad, 1 September 1929.

69 "Slank blijven," Het Vaderland: Staat- en Letterkundig Nieuwsblad, 29 September 1929.

$70 \quad$ "Het vegetarisch dieet," Het Vaderland: Staat- en Letterkundig Nieuwsblad, 27 September 1929; "Cosmiticie en Bedouinen," Algemeen Handelsblad, 20 March 1930.

71 Het Vaderland: Staat- en Letterkundig Nieuwsblad, 11 May 1928.

72 P.H. Van der Hoog, "Christenen en Mahomedanen," Het Vaderland: Staat- en letterkundig nieuwsblad, 18-April 1931.

73 Van der Hoog, "Christenen en Mahomedanen."

74 Van der Hoog, "Christenen en Mahomedanen."
} 
his mind]: Never again, because during that time he was obliged to lack all what the western life would offer, including easiness, joy, arts, music, and beauty of women." 75

Achieving a successful career was not everything that Van der Hoog wanted in life. In the Netherlands, he always remembered his "self-promise" that he had already made to return to Mecca. Concessions were sometimes necessary for man's struggle with his most sacred convictions. Now as a Muslim, he was free to perform the Hajj. In his thoughts, he recalled the scene of countless numbers of pilgrims whom he had helped; those whom he saw suffering; or those dying on the streets of Jeddah or in their caravans in the desert. Those people sold their properties and spent their wealth just to fulfill one wish: "salvation of their immortal soul." 76

Van der Hoog maintained that he had toiled, worked hard, and fought for his purpose of returning to Mecca. Despite his shortage of money and other hardships, he finally reached his goal. ${ }^{77} \mathrm{He}$ sent a letter to the King of Saudi Arabia in which he declared his conversion to Islam, asking for permission to visit Mecca. The King sent his congratulations on that step, but requested him to demonstrate his sincere faith by accomplishing various religious duties, especially prayers and fasting. He promised Van der Hoog that after living one year as a devout Muslim, he would be then allowed to come and perform the Hajj. ${ }^{78}$ With the help of some Muslim students in the Netherlands, he began to learn Arabic, became familiar with the prayer rituals, and memorized parts of the Qurānn. ${ }^{79}$ From Holland, Van der Hoog wrote again to the King saying that he had tried to live as a good Muslim, and longed to return to the Holy Land and perform the Hajj. Ibn Sa'ūd answered him: "Do come, you will be welcome in Mecca. We have not forgotten the services you rendered to our country" 80 After this invitation, there were no obstacles left barring his way to Mecca. He wrote: "as a Muslim it makes me free now to go on pilgrimage to Mecca and Medina, the Holy Cities of Islam." 1

Van der Hoog's published Hajj travelogue is the most important document of his journey. After his return from the Hajj he decided to publish this account for three reasons: 1) to give an overview of the different Muslim peoples from

\footnotetext{
75 Van der Hoog, Pelgrims, 72.

76 Van der Hoog, Pelgrims, 75 .

77 Van der Hoog, Pelgrims, 73.

78 Van der Meulen, Faces in Shem, 20.

79 Van der Meulen, Faces in Shem, 21.

$80 \quad$ Van der Meulen, Faces in Shem, 22.

81 Van der Hoog, Pelgrims, 74-75.
} 
various parts of the world who annually took part in the Hajj and the Hajj's meaning in respect of pan-Islamism; 2) to shed light on the hygienic "dangers" and diseases such as dysentery, typhus and cholera that were caused through the gathering of hundreds of thousands of Muslims in the Holy Cities every year; and 3) a purely personal account of a man who saw himself reaching the peak of his life and career, but had a sudden feeling that his accumulated experiences, knowledge and understanding throughout the years were not enough for him. As for the last point he remarked: "The storeroom of the spirit, which he thought to be full to the brim, appeared to be almost empty."82

Above all, Van der Hoog's aim of going to the Mountain of 'Arafāt was romantic. He was not satisfied with his western environment and its attendant modernity. He could not abide the big cities with their asphalt, concrete constructions, flashing illuminated signs and advertisements, and general air of selfassurance. As his voice was "drowned" by car horns, gramophones, radios and car engines, Van der Hoog longed to hear the human voices and spiritual cries of Mecca. He remembered fondly his feelings of great sympathy to the pilgrims and those who sought inner rest and peace when he came to Jeddah for the first time. ${ }^{83}$

Van der Hoog was well aware that his friends and family in Europe would find his pilgrimage journey peculiar. On the evening of his departure, he stood alone on a platform waiting for the train going South with no friends, acquaintances or family, as he did not have enough courage to see them off. But it was his earlier self-promise that drove him to leave his house, work and beloved people. "And when [I] was in the train which was hurrying to the South," Van der Hoog remembered, "leaving behind all of these things, [I] could do nothing, but whisper in humility the words the Prophet: 'God make me belong to those who repent and those whom You shall purify." "84

\section{The Journey}

In his account, Van der Hoog introduced his Dutch readers to the rites of the Hajj in a detailed way, similar to the manner in which they are mentioned in normative Muslim primary sources. Nevertheless, he sometimes digressed from his main narrative about the Hajj to deal with the Saudi religious struggle against the holy shrines and tombs, the Shī'ite-Sunnī conflicts, and the histor-

\footnotetext{
82 Van der Hoog, Pelgrims, 2-3.

83 Van der Hoog, Pelgrims, 4.

84 Van der Hoog, Pelgrims, 75-76.
} 
ical difference between the Caliphate and Imamate. ${ }^{85} \mathrm{He}$ was also sometimes inclined to accept other interpretative theories for these rituals which are not commonly accepted by orthodox Muslims. As for the stay on the mountain 'Arafāt, for example, Van der Hoog made a remarkably similar reference to his above-mentioned understanding of 'Umrah that this ceremony on 'Arafāt might have been an attenuated remnant of other religious traditions of the pagan Arabs. Probably, he stressed, 'Arafāt was a place for a big feast-offering for the Arabs before Muhammad. ${ }^{86}$

Van der Hoog made no secret of his journey. In Egypt he took a steamer to Jeddah along with pilgrims from Bukhara, Palestine and Egypt. He realized that his new experience in his brown Bedouin cloak performing the prayers on the deck of a steamer in the middle of "a flock of ragged pilgrims" made him a totally different person to the adventurous doctor who had been there seven years before. He also felt better that he could travel undisturbed and unconcerned, but was a bit ashamed of what he saw as his "past rashness" before this trip. ${ }^{87}$ On a breezy winter morning, the ship approached Jeddah. When Van der Hoog came on the deck of the boat, all pilgrims were already wearing their white ihrām clothing. Even an Arab prince who had been walking around on board during the journey in his beautiful national dress costume appeared on board in the same humble way in the white ihrārm. ${ }^{88}$

Despite the tragic scene before him of the wrecked French ship ss Asia that caught fire in Jeddah harbor and was destroyed in May 1930 with 1,500 pilgrims onboard, Van der Hoog sketched a romanticized poetic description of the scenery of Jeddah and its coral banks: "The more we get closer, the better the distant city can be seen: an accumulation of glistening white cubes between which there was one single standing minaret; above which sun rays breaking through the clouds always make it play with wonderful light effects." 89 In the western part of the city, one could easily see the buildings of consulates and diplomatic missions above which their respective flags were waving. In Jeddah Van der Hoog was received by his old friend Said Hossein al-Attas, who accompanied him as a mutawwif (guide) during the Hajj. Finally, after many years, Van der Hoog landed on Arabian soil. ${ }^{90}$

\footnotetext{
85 Van der Hoog, Pelgrims, 82-97.

86 Van der Hoog, Pelgrims, 79.

87 Van der Hoog, Pelgrims, 99.

88 Van der Hoog, Pelgrims, 100.

89 Van der Hoog, Pelgrims, 101.

9o Van der Hoog, Pelgrims, 101.
} 


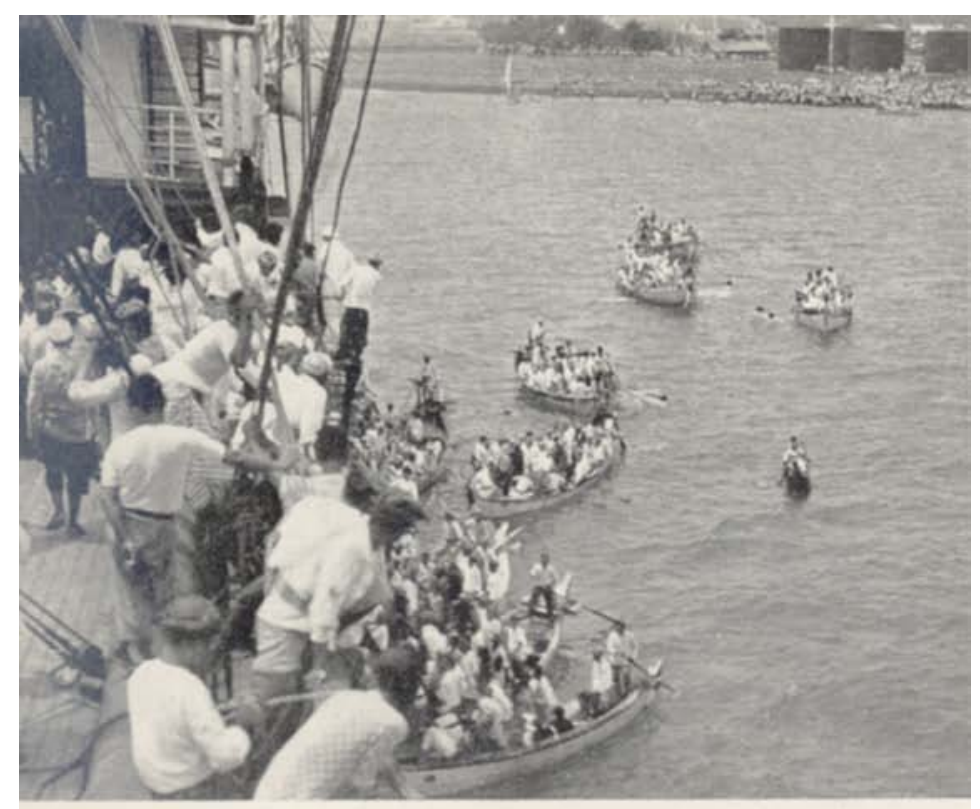

XVIII. Pelgrims komen aan boord

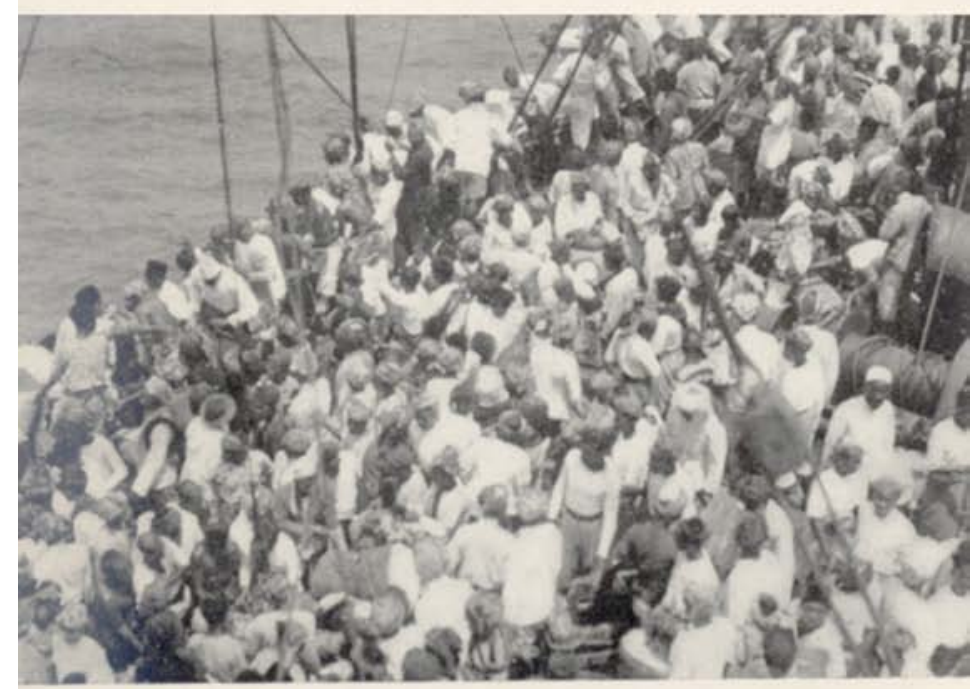

XIX. Het dek van een Pelgrimsboot

FIGURE 7.1 Pilgrims on board in Jeddah (taken from Van der Hoog's book). Dutch captions read as follows: XVIII. Pilgrims coming on board XIX. The deck of a pilgim boat. 
In Jeddah, he could not immediately continue his journey to Mecca. He had to stay because some European patients pleaded for his help, since the Muslim doctors linked to European legations had already left for Mecca during the Hajj season. ${ }^{91}$ Van Der Hoog recalled his memories of those who died during the cholera epidemic in 1893. Dead bodies were heaped on the streets, before the Conseil Quarantenaire d'Egypt had sent six doctors, six pharmacists and other medical equipment to deal with the epidemic in that year. ${ }^{92}$ "No wonder," Van der Hoog wrote, "that many members of the European colony had died [in Jeddah]." ${ }^{93}$ He paid a visit to the Christian cemetery in Jeddah where many Europeans were buried. His first attention focused on the Dutch names on the grave signs who died in Jeddah, such as H.V.D. Houwen van Oordt (18651892), the Dutch consul in Jeddah, Pieter Nicolaas van der Chijs (1858-1889), the Dutch vice-consul, and a certain Frederik Gerardus van der Zee (1886-1910). ${ }^{94}$

Van der Hoog left Jeddah for Mecca taking the Medina road. Reciting the formula of the Hajj Labbayka Allāhuma Labbayka (Here I am, O Allah), he first drove though arid sands where tufts of grass were growing here and there. In the car, a fierce cold wind was whizzing through his ears. In Mecca, Van der Hoog was hosted by some of his old friends. He noted that it was an unforgettable moment when he entered the Haram of the Mecca Mosque with his friend Said al-Attas. In his own words: "we directed our steps to the Ka'ba. There she lies ahead to us, a big black cube surrounded by a band of gold characters, center of the whole Muslim world." ${ }^{95}$ Close to the Black Stone, the Arab soldiers keeping guard of the stone noticed that Van der Hoog, as the only European in the crowd, wanted to reach the stone. They delicately pushed the people aside for him till he reached the place. In the depth of the wide oval silver frame, Van der Hoog watched a pitch-black stone glistening therein. He pressed his body to the Ka'ba, "kissing her, just as a man taking a long-coveted woman in his possession." 96

As for other prescribed rituals, Van der Hoog drank from the water of Zamzam which he had earlier criticized for its unsafe nature. ${ }^{97}$ During his performance of the ritual of running between the hills of al-Ṣafā wal-Marwah, Van der Hoog suddenly remembered his two sons in Holland and what they would think of their father in this state of the Muslim Pilgrimage, when they grew up:

\footnotetext{
91 Van der Hoog, Pelgrims, 102.

92 Van der Hoog, Pelgrims, 102.

93 Van der Hoog, Pelgrims, 102.

94 Van der Hoog, Pelgrims, 104-105.

95 Van der Hoog, Pelgrims, 108.

96 Van der Hoog, Pelgrims, 110-111.

97 Van der Hoog, Pelgrims, 110.
} 


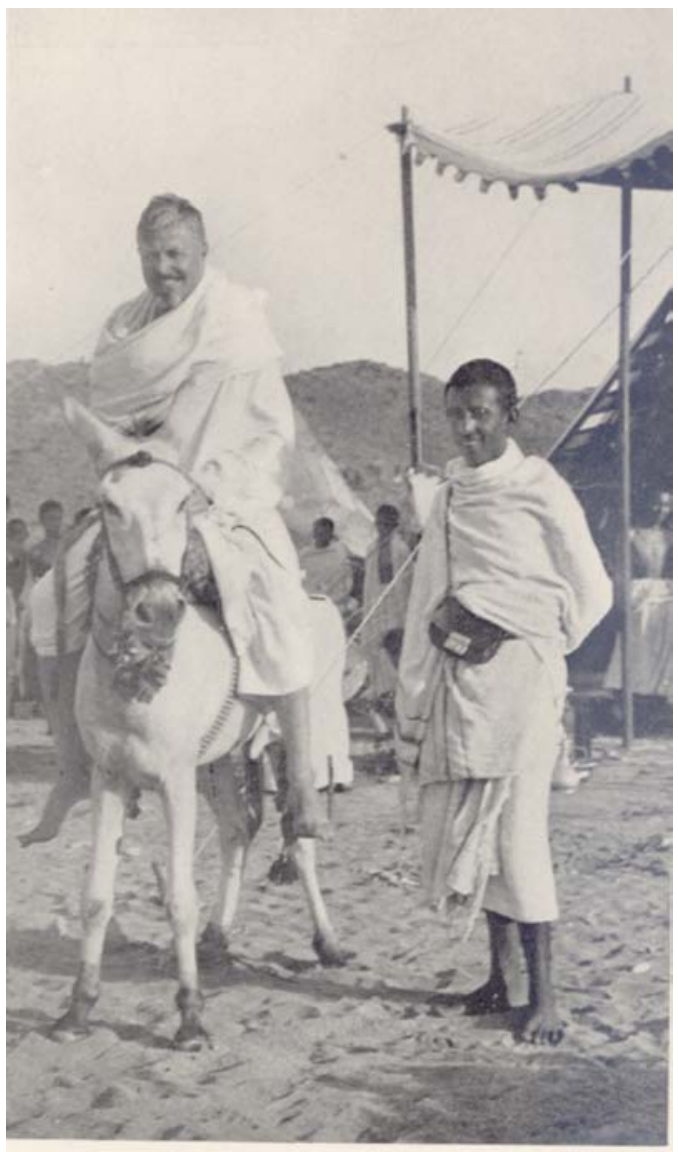

De auteur op zijn ezel in de vlakte van Arafah
FIGURE 7.2

Van der Hoog on his donkey on the Mountain of 'Arafät (taken from Van der Hoog's book). Dutch caption reads: The author on his donkey at the plain of Arafah.

They will perhaps shyly smile when they read this account of my pilgrimage and will find it a bit crazy that their "old lord" on his bare feet with two white rags around his body there amid of thousands of other pilgrims from all over the world walking to and fro between the two hills. But when they are older and remember all of this, they will probably appreciate it that their father was thinking of them during the very strangest moment of his life, just as Hagar had thought of Ismael. My doing will therefore find mercy in their modern eyes. I hope this at least. ${ }^{98}$ 


\section{The Kiswah of Ka'ba as Medical Fees}

During his visit in Mecca, Van der Hoog was gifted a piece of the black curtain covering the Ka'ba (known as Kiswah) by his friend Qāsim al-Khalīl, a wealthy merchant in Mecca, in return for helping his pregnant wife during the birth of their child. Shortly after Van der Hoog's arrival in Mecca, he was called at 6 o'clock in a morning by al- Khalil and the latter's father-in-law to come and help his beautiful fifteen year old wife experiencing a complicated labour. When Van der Hoog arrived at the door of the women's room, the ladies inside refused to let him in, and screamed that they would jump from the window if a strange man entered the room. As for the prospective father, Van der Hoog told us, "he stood there like a beaten dog. It is not thus a pleasant scene to see many beautiful women fluttering on the rocks into pieces [... from] the third floor." ${ }^{\prime 9}$ After six hours, the women inside became distressed and Van der Hoog was finally admitted in. After a successful delivery of a son, Van der Hoog maintained that he, as a European doctor, had broken a "harem record" for Mecca. ${ }^{100}$ "To my female readers," Van der Hoog said, "who shall be of course most interested to know, I should inform them that the child was a boy and his father named him Khalid." ${ }^{101}$ As for his medical peers, who might be interested to know the fee he calculated for his work, his fees for the treatment were a beautiful piece of the golden brocade of the Kiswah. ${ }^{102}$ As the curtain was replaced every year, it was cut into pieces which were usually sold or gifted as relics to Muslim dignitaries and converts. Throughout history, the Kiswah was manufactured in Egypt; this tradition continued till 1927 when King Ibn Sa'ūd ordered the establishment of a factory for its manufacturing in Mecca. During his stay in Mecca, Van der Hoog visited this factory where the Kiswah was usually woven. The director, who proudly called himself "Minister of the Holy Carpet," was van der Hoog's tour guide. ${ }^{103}$ The curtain is usually made of black brocade. ${ }^{104}$

\footnotetext{
99 Van der Hoog, Pelgrims, 113.

100 Van der Hoog, Pelgrims, 114.

101 Van der Hoog, Pelgrims, 114.

102 Van der Hoog, Pelgrims, 114.

103 A. Gouda, "Die Tirāz-Werkstätten der Kiswa für die Ka'ba in Makka: ein Beitrag zur islamischen Textilgeschichte," Der Islam 71.2 (1994): 289-301 Aḥmad 'Abd al- Ghafūr 'Aț̣ār, Al-Ka'ba wa-l-kiswa munz arba'at àlāf sana hattā al-Yawm (Makka: [s.n.], 1977).

104 Van der Hoog, Pelgrims, 116.
} 


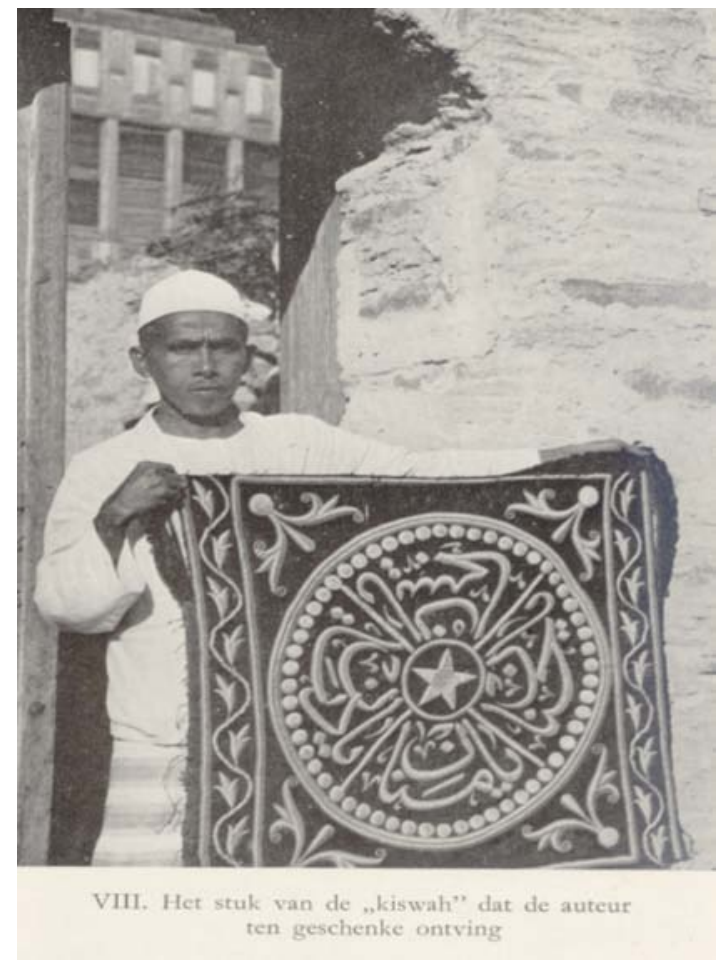

FIGURE 7.3

Van der Hoog's piece of the

Kiswah of Ka'ba (taken from Van der Hoog's book). Dutch caption reads VIII. A piece of the kiswah that the author received as a gift.

The Saudi Royal Family

One of Van der Hoog's unforgettable moments was meeting with Prince Faișal in Mecca. Van der Hoog was invited by Ibrāhīm Bey, Prince Faișal's father-inlaw, to accompany him to a nearby madrasa where the members of the royal family were staying and where the prince would come and greet Muslim leaders and notables. Van der Hoog had met with Prince Faișal a few years before during his diplomatic visit to The Hague in 1928. But the meeting in Mecca was different as it made a greater impression on him: "a fairy tale from the Thousand and One Nights: memorable due to his Oriental splendor of color and his perfect beauty in form and grace of movement." 105 Van der Hoog found that Prince Faișal's face became more "powerful" at that time than during his visit to The Netherlands. He began to look like his grandfather Āl Sa ${ }^{c} \bar{u} d .{ }^{106}$ As a thirty-three year old young man, Van der Hoog went further, he enjoyed a Bedouin upbringing, which might not have been the most suitable training for

105 Van der Hoog, Pelgrims, 137.

106 Van der Hoog, Pelgrims, 139. 
his position as a minister of Foreign Affairs, in Van der Hoog's opinion. However, he remained "a bold fighting General and first-class equestrian."107

In the evening Van der Hoog was invited to a reception at the Royal Palace on the outskirts of Mecca where King Ibn Sa'ūd was supposed to meet Muslim leaders and notables as well. The King and some of the politicians and notables present delivered various speeches on the significance of Muslim unity and the significance of the Hajj as a symbol for such unity. This experience of two hours of speeches was, for Van der Hoog, a tangible illustration of "the dream of panIslamism" during the Hajj season. ${ }^{108}$

Van der Hoog's pilgrimage was in the same year when three Yemeni armed men made a futile assasination attempt on King Ibn Sa'úd during his performance of Hajj on March 15, 1935. The King survived the attack unhurt, and Van der Hoog listened to rumors among the pilgrims about the attack. Mecca was in a state of commotion. Remarkably enough, Van der Hoog did not consider the assault as a political assassination attempt. According to him, when they came down from 'Arafāt, they saw the King on his horse collecting the stones of Jamarät like any other pilgrim. Then he went in a car to Mecca in order to walk between al-Ṣafaā and al-Marwa. His guards pushed the other pilgrims away, while a few Yemenis were protesting that in the House of God every pilgrim should have the same rights as the King. The three Yemenis rushed at the King with their daggers drawn, but were killed by the King's guards. Later the King and his wounded son, Prince Sa ūd, continued their tawāf. The former king of Afghanistan, who was in the company of King Ibn Sacud at that time, fled the mosque after the assault, an action which provoked hilarity among the people in Mecca. ${ }^{109}$ When Van der Hoog came to the Haram to fulfill his tawäf, people were still busy cleaning the blood off the marble floor around the Kaba. He was told that during the turmoil, all the Yemeni pilgrims were hounded out of the Haram and were later disarmed. ${ }^{110}$

Van der Hoog was pleased that the King was rescued, who due to his "personality" and "powerful hand" was holding the Kingdom together. ${ }^{111}$ The royal family organized a reception in Mina in a big tent in front of the Palace, where the Crown Prince received prominent guests who came to express their relief at the happy ending of the incident. In the reception hall of the Palace, the

\footnotetext{
107 Van der Hoog, Pelgrims, 140-141.

108 Van der Hoog, Pelgrims, 142-149.

109 Van der Hoog, Pelgrims, 157-158.

110 Van der Hoog, Pelgrims, 158.

111 Van der Hoog, Pelgrims, 159.
} 
King appeared surrounded by heavy armed guards, who were mainly slaves. Together with other guests, Van der Hoog greeted the King, kissing his hand. ${ }^{112}$

\section{Mecca as a City}

In a separate chapter of his account, Van der Hoog laid out a heavy critique of Mecca as a city where he encountered new, unfamiliar habits. He toured the city and enjoyed the scenery of its hills, especially Jabal Hindī. However, Mecca was, in his perception, like a "dirty furry animal" which had acted like a parasite on the vitality of others for centuries. ${ }^{113}$ However, in Van der Hoog's view, as someone who had evidently not divested himself of all European and western influences and perceptions, Mecca (despite its holiness and devotion) was nothing but a filthy and dirty town: "But those who totally submitted themselves for her, she will tell them significant truths of life."114

He visited the Takiyya, the Egyptian Hospice in Mecca, where he was received by its Egyptian director Fu'ād Bey and its medical doctor Mușțafā. Van der Hoog was shocked by the extreme level of poverty among the people coming to the hospice. He appreciated the benevolent "great job" that the Egyptians were undertaking, even though it was fulfilled in order to support their political position as a leading Muslim power. Van der Hoog furthermore compared the misery in Mecca with what people in Europe would understand under the term "poverty":

If you have not seen any poverty in your life, come [to Mecca] and you shall get its meaning here. In Europe one believes that he sometimes knows what poverty means [...] But in Europe a poor person always possesses something, even when it is a few tea cups without handles, a mattress, or a set of clothes to cover his body. Here in Mecca there are people who own completely nothing; nothing but their sick and emaciated body. But this is only good in order to let the rich realize how good we have it here on this earth. ${ }^{115}$

In Mecca, Van der Hoog fell very sick. During long hours of perspiring, lying on his mattress with a dry throat, he remembered the scenery of Jabal Hindī

\footnotetext{
112 Van der Hoog, Pelgrims, 160.

113 Van der Hoog, Pelgrims, 120.

114 Van der Hoog, Pelgrims, 123.

115 Van der Hoog, Pelgrims, 121.
} 
that he had enjoyed some weeks before. ${ }^{116}$ His tough experience of illness and weakness at that moment taught him to look afresh at modern life and civilization. He rhetorically indicated that instead of being a slave of civilization, man should always try to be her master. In Europe, a few telephone calls were enough for a man to get a good health care: "the modern man is the son of the nature. He lost his mother while standing there helpless and lonely deprived of her good care."117

Van der Hoog was confronted by the great diversity among the pilgrims from different regions. He found that it was only in places beyond Europe that produced such paradoxes. One human example of this was a poor Senegalese man in rags who had left his village three years earlier by travelling on foot in order to perform the Hajj. People like this who "had no compass, except their faith" greatly impressed Van der Hoog. ${ }^{118}$ One example that contrasted greatly with the case of this Senegalese man was the Indian prince Nawab of Bahawalpur, who arrived in Jeddah with a huge retinue, with his own bodyguards and thirty automobiles. ${ }^{119}$

In Mecca, Van der Hoog had a feeling of otherness. As a European, he felt that his appearance in the Haram during prayer times was sometimes striking, given the gaze and attitudes of other fellow worshippers. Whenever he tried to sit quietly on his prayer mat in the Haram courtyard, various people would immediately come and talk with him out of curiosity. One of those people was Mohammed Ali al-Chougier, a retired Shafi'ite imam, who, in Van der Hoog's view, was appointed by the Hijāzi government as an "inquisitor" who ensured that people followed the rules of Islam: "I felt his friendly visit a little bit like a control measure."120

\section{The Great Day of 'Arafāt}

In many remarkable passages, Van der Hoog philosophized about his calm moments during the rituals on the mountain of 'Arafāt and Jabal al-Raḥma (Mountain of Mercy). He decided to climb alone to the hilly space of 'Arafāt before thousands of pilgrims started to flock there. After this, in the early

\footnotetext{
116 Van der Hoog, Pelgrims, 122.

117 Van der Hoog, Pelgrims, 126.

118 Van der Hoog, Pelgrims, 128-129.

119 Van der Hoog, Pelgrims, 129.

120 Van der Hoog, Pelgrims, 131-132.
} 
morning, he drove by car, and after twenty minutes arrived in Mina, which was for him a symbol of both Biblical and Islamic narrations. ${ }^{121}$

One can discern that by performing the Hajj as a European Van der Hoog experienced a remarkable strangeness, a feeling of entering another world. On the day of 'Arafāt, the peak moment of the entire Hajj, Van der Hoog felt that he had reached the final stage of his spiritual experience. Other friends decided to go to 'Arafāt on camels. But this way seemed boring and monotonous to Van der Hoog. Therefore, he hired a donkey for the journey to 'Arafāt, which was one of the most fantastic journeys in Van der Hoog's life. On the back of his donkey, he firmly stacked his luggage, a mattress, pads, blankets, and clothes and a big bag of water. He greatly enjoyed his eighteen-kilometre tour on his moveable "unsteady throne" in the desert. An Arab donkey, Van der Hoog wrote, was the most wonderful animal that ever existed. ${ }^{122}$

Despite the crowds of pilgrims everywhere on camels, donkeys or walking, a mood of peace and pleasure was spreading among the pilgrims. When Van der Hoog's donkey almost ran into a Moroccan pilgrim, he kindly answered, " $m a^{c}$ lish" (Never mind). ${ }^{123}$ In the early evening under the light of street lantern, Van der Hoog felt as if there had been a "river of white figures streaming" to the hill of 'Arafāt. ${ }^{124}$ By finishing the ritual on 'Arafāt, the peak of Van der Hoog's pilgrimage, the subsequent part of the Hajj did not match the peak of this experience, however interesting they might be. ${ }^{125}$

After finishing the Day of 'Arafāt, Van der Hoog remarked that the "imposing" and "heart-felt" crowd which he had earlier described no longer existed. The whiteness of pilgrims' Ihrām clothes had become dirty, and most pilgrims had already put on their normal clothes. One could not distinguish the poor from the rich and different nationalities: "it is not the same unanimity inspired by the idea of 'People of God' anymore, which I had seen passing through the last days. Something was lost, but I do not know what?"126

Van der Hoog continued to perform the remaining Hajj rituals. During the throwing of Jamarāt, he observed a similar crowd of pilgrims. He was surprised sometimes some zealous Bedouins would grab their revolvers and fire shots at the pillars, these symbols of the devil. ${ }^{127} \mathrm{He}$ also had two sheep offered up

\footnotetext{
121 Van der Hoog, Pelgrims, 134-135.

122 Van der Hoog, Pelgrims, 150.

123 Van der Hoog, Pelgrims, 151.

124 Van der Hoog, Pelgrims, 151.

125 Van der Hoog, Pelgrims, 156.

126 Van der Hoog, Pelgrims, 160.

127 Van der Hoog, Pelgrims, 161.
} 
on the Day of Sacrifice. He was positive about the government's new strict regulations which had been recently introduced to centralize the slaughtering of animals in one place; and that the leftovers of slaughtered animals were directly thrown away in pits that were then disinfected with lime. In that year, Van der Hoog observed, there was a relatively healthy atmosphere: "the Health Services of the Hijāz, despite its scant resources, did their best [in that regard]." ${ }^{128}$

After throwing the last stones and observing the ritual prayers, Van der Hoog felt that by so doing the pilgrims had "sincerely tried to drive the devil out."129 His donkey was loaded again in order to get back home. Along the way, he passed by the Jabal al-Nūr (Mountain of Light), where the Prophet Muhammad was said to have preached his Farewell Sermon. During his last tawāf, Van der Hoog sat in between two rows of soldiers and a small, thin, old lady wrapped in heavy yellow silk dress and leaning on her stick, who was in deep reverence before the Black Stone. He was told that she was the Rani of Hyderabad. ${ }^{130}$

The Day of 'Arafāt was Van der Hoog's peak experience of the Hajj. In his opinion, a man should take the path to 'Arafât at least one time in his life in order to achieve a deep conviction that this path really exits. Under the Haram's portico, Van der Hoog sat and cast a last glance at what he saw as "precious images" deeply engraved in his thoughts: the Kaba, the slender minarets, the high houses of Mecca, the mountains, the hundreds of blue doves. Finally, before he left Mecca, he wondered if he would see these images again. ${ }^{131}$

\section{Popularizing the Hajj to the Dutch Audience}

Ultimately, Van der Hoog was able to fulfill the entire ritual. After his return to the Netherlands in 1935 , he began to publicise the account of his journey in the Dutch press. Among the many themes he wrote about was Ibn Sinā (Avicenna) and other topics related to medicine and science in Islam. ${ }^{132} \mathrm{He}$ also conducted several public courses at the Volksuniversiteit in Leiden on Islam,

\footnotetext{
128 Van der Hoog, Pelgrims, 162.

129 Van der Hoog, Pelgrims, 163.

130 Van der Hoog, Pelgrims, 163.

131 Van der Hoog, Pelgrims, 164.

132 "De weg naar Arafah: een moderne pelgrimstocht," Het Vaderland: Staat- en Letterkundig Nieuwsblad, 24 February 1935; "Mekka en de wereld der Arabieren: Dr. P.H. van der Hoog onder de Pelgrims," Het Vaderland: Staat- en Letterkundig Nieuwsblad, 24 November 1935. See, P.H. van der Hoog, Ik, Ibn Sina (The Hague: Zuid-Holl. Uitg. Mij., 1937).
} 
modern Arabia, the Hajj and pan-Islamism. ${ }^{133}$ In $1938-1939$, as an experienced prominent Dutch pilgrim, Van der Hoog introduced the documentary film Het Groote Mekka Feest (The Great Mecca Festival) by the Dutch-Indonesian Muslim filmmaker G. Krugers (d. 1937) to the public, when Dutch cinemas and theatres in The Hague screened the film after Kruger's death. ${ }^{134}$

\section{Conclusion}

Van der Hoog's account of the Hajj is indeed a western religious experience which demonstrates that the pilgrim in question did not completely distance himself from his culture of origin. It is a humoristic and vivid literary and autobiographical document of a western Muslim narrator who mixed with another culture for a period of time without suppressing his identity as a Dutchman. Van der Hoog was no "assimilationist," whose aim was either assimilate himself in the Islamic culture, or to incorporate western thought into Islam. He was merely an intermediary figure embarked on an adventure of a lifetime to fulfill an ultimate spiritual goal in the Hajj, at least as he had imagined it.

Imbued by his devout Christian faith, the Dutch consul in Jeddah, Van der Meulen, was unconvinced about Van der Hoog's conversion to Islam. A few years after Van der Hoog's death, the Dutch consul wrote that on the plains of 'Arafāt and Minā Van der Hoog "suffered as a doctor because he couldn't believe as a believer. Now that the forbidden land was no longer forbidden to him, it lost its attraction."135 However, a careful reading of Van der Hoog's Hajj narrative reveals the story of a European adventurer in a search for new spiritual experiences. Van der Hoog held a mystical Unitarian vision of religion. Islam was just a religious manifestation of the absolute truth which could be

133 "Arabie en de bedevaart naar Mekka," Het Vaderland: Staat- en Letterkundig Nieuwsblad, 11 February 1937.

134 "Pelgrimstocht naar Mekka: een belangwekkende film," Het Vaderland: Staat- en Letterkundig Nieuwsblad, 20 October 1938; cf. "Oostersch Genootschap in Nederland: Congres te Leiden," Algemeen Handelsblad, 5 April 1939; "De Mekka Film," Het Vaderland: Staat- en Letterkundig Nieuwsblad, 11 February 1939. In the late 1920s Krugers went with a camera on Hajj to film the ritual for the first time, which is a unique snapshot of the Hajj experience, and of life in Arabia of that time. The premiere of that film took place in 1928 in Leiden with an introduction by Snouck Hurgronje, which was a redcarpet event attended by the then nineteen-year old Princess Juliana of the Netherlands. http://www.geschiedenis24.nl/nieuws/2012/oktober/Het-groote-Mekka-feest.html ?goback=\%2Egmr_117118\%2Egde_117118_member_179052491 (accessed, 11 Dec. 2012).

135 Van der Meulen, Faces, 23. 
found in all religious orientations. Throughout his account, he did not take all Islamic institutions or traditions for granted. Regarding the Hajj in particular, he was ready to accept several contemporary critical approaches to the history of the Hajj by Orientalists, which claimed that there were pre-Islamic pagan remnants in the Islamic Hajj rites. During his stay in Arabia, nevertheless, Van der Hoog stated in a press article that his Hajj should be seen as a "modern" pilgrimage. Despite the fact that he himself had warned many against the epidemic dangers of Hajj journey in the press, he dared to take the risk of performing the ritual only because of this new spiritual endeavor. ${ }^{136}$

From the late 1930s, Van der Hoog's formalistic connection to Islam and its religious practices and duties most likely evaporated. He continued writing about his reflections on human physical and spiritual suffering. His book on Ibn Sinā was well received and reprinted several times. ${ }^{137}$ The general public knew about his earlier Hajj adventure, but he scarcely spoke about it again with his family. His daughter, Fatima Gudde-van der Hoog, told me in an interview that her father remained until the end of his life a believer in one God, but was no longer a practicing Muslim. She still remembers that he used to receive "Oriental-looking" Muslim men at home in The Hague after the Second World War. Her father even donated money to the building of the first mosque in The Hague that was established in $1955 .{ }^{138}$

As part of Dutch intellectual history, Van der Hoog certainly introduced a specific image about Islam, Arabia and the Hajj to the Dutch public in the interwar period. His conversion to Islam, his pilgrimage and name as Abd al-Ali (a translation of his name in Dutch) are far less well-known among the Dutch public nowadays than the fame of his name on all the cosmetic preparations and creams, still produced by the skin care company under the name Dr. Van der Hoog.

\section{Bibliography}

\section{Dutch Newspaper Articles}

"Arabie en de bedevaart naar Mekka," Het Vaderland: Staat- en Letterkundig Nieuwsblad, 11 February 1937.

\footnotetext{
136 See his article, "De weg naar Arafah: een moderne Pelgrimstocht," Het Vaderland: Staat-en Letterkundig Nieuwsblad, 24 February 1935.

137 Van der Meulen, Faces, 24.

138 Interview, op. cit.
} 
"Christenen en Mahomedanen," Het Vaderland: Staat- en letterkundig nieuwsblad, 18April 1931.

"Christen-Islamieten: Toestanden in en om Mekka," Het Nieuws van den Dag voor Nederlandsch-Indië, 14 January 1930.

"Christen-Islamieten: Toestanden in en om Mekka," Het Nieuws van den Dag voor Nederlandsch-Indië, 14 January 1930.

"Cosmiticie en Bedouinen," Algemeen Handelsblad, 20 March 1930.

"De Mekka Film," Het Vaderland: Staat- en Letterkundig Nieuwsblad, 11 February 1939.

"De weg naar Arafah: een moderne Pelgrimstocht," Het Vaderland: Staat- en Letterkundig Nieuwsblad, 24 February 1935.

"Dr. F.H. Van der Hoog naar Djedda," Het Vaderland: Staat- en Letterkundig Nieuwsblad, 14 September 1928.

"Dr. P.H. van der Hoog over de Watervoorziening”, Amigoe di Curacao: Weekblad, 14 August 1926.

"Een slachtoffer," Het Nieuws van den Dag voor Nederlandsch-Indië, 19 March 1915.

"Gezichtsmassage," Het Vaderland: Staat- en Letterkundig Nieuwsblad, 1 September 1929.

"Het overtollige haar," Het Vaderland: Staat- en Letterkundig Nieuwsblad, 11 August 1929.

"Het vegetarisch dieet," Het Vaderland: Staat- en Letterkundig Nieuwsblad, 27 September 1929.

"Indische Kroniek: Oude bekenden in de buurt van Mekka," Algemeen Handelsblad, 15January 1930.

"Ingezonden: De Officiersvereeniging," Bataviaasch Nieuwsblad, 18 January 1915.

"Leelijke Beenen," Het Vaderland: Staat- en Letterkundig Nieuwsblad, 7 July 1929.

"Mekka en de wereld der Arabieren: Dr. P.H. van der Hoog onder de Pelgrims," Het Vaderland: Staat- en Letterkundig Nieuwsblad, 24 November 1935.

"Nederlander in de Hedjas", Het Vaderland: Staat- en Letterkundig Nieuwsblad, 25 January 1928.

"Nederlansch-Indie: De Bedevaart naar Mekka", Bataviaasch Nieuwsblad, 17 September 1928.

"Oostersch Genootschap in Nederland: Congres te Leiden", Algemeen Handelsblad, 5 April 1939.

"Pelgrimstocht naar Mekka: een belangwekkende film," Het Vaderland: Staat- en Letterkundig Nieuwsblad, 20 October 1938.

"Slank blijven," Het Vaderland: Staat- en Letterkundig Nieuwsblad, 29 September 1929.

"Ter Bedevaart," Soerabaijasch Handelsblad, 10 January 1930.

"Vaarwel," Amigoe di Curacao: Weekblad voor de Curacaosche Eilanden, 2 October 1926.

"Verzorging van handen en nagels," Het Vaderland: Staat- en letterkundig Nieuwsblad, 14 July 1929.

"Watervoorziening," Amigoe di Curacao: Weekblad voor de Curacaosche Eilanden, $21 \mathrm{Au}-$ gust 1926. 
Algemeen Handelsblad, 1 August 1913.

Algemeen Handelsblad, 22 April 1914.

Algemeen Handelsblad, 28 February 1923.

Amigoe di Curacao: Weekblad voor de Curacaosche Eilanden, 13 February 1926; 3 April 1926; 17 July 1926.

Amigoe di Curacao: Weekblad voor de Curacaosche Eilanden, 28 August 1926.

Bataviaasch Nieuwsblad, 10 March 1913.

Bataviaasch Nieuwsblad, 15 June 1921.

Bataviaasch Nieuwsblad, 18 January 1915.

Bataviaasch Nieuwsblad, 19 March 1914.

Bataviaasch Nieuwsblad, 25 March 1914.

Bataviaasch Nieuwsblad, 29 July 1913.

Bataviaasch Nieuwsblad, 8 July 1916.

De Tijd: Godsdienstig-staatkundig Dagblad; 20 June 1911.

De Tijd: Godsdienstig-staatkundig Dagblad; Algemeen Handelsblad, 5 February 1913.

Het Nieuws van den Dag voor Nederlandsch-Indië, 11 September 1913.

Het Nieuws van den Dag voor Nederlandsch-Indië, 17 March 1913.

Het nieuws van den Dag voor Nederlandsch-Indië, 26 August 1913.

Het Nieuws van den Dag voor Nederlandsch-Indië, 27 March 1914

Het Nieuws van den Dag: Kleine Courant, 15 July 1907.

Het Nieuws van den Dag: Kleine Courant, 16 April 1913.

Het Nieuws van den Dag: Kleine Courant, 23 April 1914.

Het Nieuws van den Dag: Kleine Courant, 3 December 1908.

Het nieuws van den Dag: Kleine Courant, 5 February 1913.

Het Vaderland: Staat- en Letterkundig Nieuwsblad, 11 May 1928.

Nieuwe Rotterdamsche Courant, 16 March 1922.

Nieuwe Rotterdamsche Courant; Algemeen Handelsblad, 1 March 1912.

Nieuwe Rotterdamsche Courant; Algemeen Handelsblad, 10 January 1913.

Nieuwe Tilburgsche Courant, 2o June 1911.

\section{Published Sources}

'Aț̣āā, Aḥmad 'Abd al-Ghafūr, Al-Ka'bawa-l-kiswa munz arba'at ālāf sana hattā alYawm (Makka: [s.n.], 1977).

Cumming, Hugh S., "The International Sanitary Conference," American Journal of Public Health 16.10 (1926): 975-980.

Gouda, A., "Die Tirāz-Werkstätten der Kiswa für die Kacba in Makka: ein Beitrag zur islamischen Textilgeschichte," Der Islam 71.2 (1994): 289-301.

Hoog, P.H. van der, Ik, Ibn Sina (The Hague: Zuid-Holl. Uitg. Mij., 1937).

Hoog, P.H. van der, Pelgrims naar Mekka (The Hague: H.P. Leopold's Uitg.-Mij, NV, 1935).

Hoog, P.H. van der, De Bestrijding der Geslachtsziekten (Leiden University, 1922). 
Howard-Jones, Norman, The scientific background of the International Sanitary Conferences (Genevan: World Health Orgainzation, 1975).

Hurgronje, C. Snouck, Mekka in the Latter Part of the 19th Century: Daily Life, Customs and Learning: The Moslims of the East-Indian Archipelago, introduced by Jan Just Witkam (Brill, 2007).

Kramer, Martin, Islam Assembled: The Advent of the Muslim Congresses (New York: Columbia University Press, 1986).

Meulen, D. van der, Don't you hear the thunder: A Dutchman's life story (Brill, 1981).

Meulen, D. van der, Don't you hear thunder?: A Dutchman's Life Story (Brill: 1981).

Meulen, D. van der, Faces in Shem (London: John Murray, 1961).

Nagazumi, Akira, "Prelude to the formation of the Perhimpunan Indonesia: Indonesian student activity in the Netherlands in 1916-1917," Proceedings of the seventh IAHA conference, held in Bangkok, 22-26 August 1977 (Bangkok: Chulalongkorn University Press, 1979), 192-219.

Poeze, H.A., "Early Indonesian emancipation: Abdul Rivai, van Heutsz, and the Bintang Hindia," Bijdragen tot de Taal-, Land- en Volkenkunde 145/1 (1989): 87-106.

Poeze, H.A., In het land van de overheerser I: Indonesiërs in Nederland 1600-1950 [In the land of the ruler I: Indonesians in the Netherlands 1600-1950] (Dordrecht: Foris, 1986).

Ryad, Umar, "Among the believers in the land of the colonizer: Mohammed Ali van Beetem's role among the Indonesian community in The Netherlands in the interwar period," Journal of Religion in Europe 5.2 (2012): 273-310.

Ryad, Umar, "Te gast in Den Haag-discussies moskeebouw in Nederland vóór de Tweede Wereldoorlog," Tijdschrift voor religie, recht en beleid 4.2 (2013): 59-78.

Sealey, Anne, "Globalizing the 1926 International Sanitary Convention," Journal of Global History 6.3 (November 2011): 431-455.

Vermeulen, Joos, Sultans, slaven en renegaten: de verborgen geschiedenis van de Ottomaanse rijk (ACCO, 2001).

http://www.drvanderhoog.nl/

http://www.geschiedenis24.nl/nieuws/2012/oktober/Het-groote-Mekka-feest.html ?goback=\%2Egmr_117118\%2Egde_117118_member_179052491 (accessed, 11 Dec. 2012). 